\title{
An Epizootic of Sendai Virus Infection in a Rat Colony
}

\author{
Susumu MAKINO, Shōji SEKO, Hiroyuki NAKAO \\ and Katsumi MIKAZUKI
}

\author{
Aburahi Laboratories, Shionogi \& Co, Ltd., Koka-cho, Shiga-Ken, Japan
}

(Accepted for publication: August 17, 1973)

\begin{abstract}
The epidemics of Sendai virus characterized by snuffles occurred repeatedly at intervals of 8 to 10 months in a rat breeding colony of approximately 500 animals. Outbreaks spread out over the whole colony rapidly and persisted for 2 to 3 weeks, but sometimes a limited incidence of snuffles was observed at 2 to 6 weeks after the termination of epidemics. During each epidemic, the delayed growth of youngs and the decreased weaning rate were observed. At autopsy of rats having shown snuffles the red consolidation was found in the lungs, from which a hemagglutinating virus was isolated and identified as Sendai virus by HI test. In animals exposed to the infection, there was a significant elevation of Sendai virus HI antibody titer coincidentally with each outbreak and the antibody was detectable even one year later. The rats born after the termination of an epidemic, however, had no antibody until the next outbreak. Mycoplasma was isolated from the lungs in one epidemy during a 2 year period. These findings might represent an epidemiological pattern of Sendai virus in a rat breeding colony where susceptible animals attain periodically a population large enough to provoke a new outbreak. [Exp. Animals, 22(4), 275-280,1973.]
\end{abstract}

\section{ラットコロニーで観察されたセンダイウイルスの 流行について}

牧野 進・瀬古 彰司 -中尾 博之 -三日月勝見

塩野義製薬株式会社油日ラボラトリーズ

ラットにおけるセンダイウイルスの感染には Par$\operatorname{ker}$ ら[1], 朱宮ら〔2]の報告があるが，その疫 学的知見については充分な報告がない。

1961年に barrier system 維持のラットを当所に 導入し， 9 年間に亘る繁殖育成過程で，スナッフルを 主徴とする呼吸器病の発生が間けつ的にくりかえし観 察された。1968年の発生時には, 血球凝集性ウイルス が分離され，センダイウイルスに対する $\mathrm{HI}$ 抗体の上 昇がみとめられた。そこで, 著者らは呼吸器病の発生 状況, 症状と, センダイウイルス, Mycoplasma と の関連を調べるため本調査を実施した。

\section{材料および方法}

動物および餖育管理：1961 年に Charles River Breeding Laboratories から導入した雌 4 匹, 雄 2 匹から育成された SD 系ラットコロニーを調査対象と した。コロニーの大きさは400〜 500匹で，その月平均 交配数は18匹，月平均離乳仔総数は110 匹であった。 また，継代用の親は原則として 2 産目の仔を用いた。 1968年 7 月以後は子宮切断術により得た Wistar 系 ラットが同じ飼育室に導入されたが，その匹数は50匹

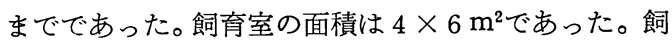
育室内の温度は $25^{\circ} \mathrm{C} \pm 2{ }^{\circ} \mathrm{C}$ に調節し, 湿度は除湿器 
で70\%以下を保つようにした。夏季には，クーラーで 外気を直接取り入れ温度を調節した。当飼育室と約 5 $\mathrm{m}$ の距離にセンダイウイルス污染のあるマウス育成場 が隣接していた。

飼育者は前室にて脱衣, $121^{\circ} \mathrm{C}, 30$ 分蒸気滅菌済の 帽子，マスク，衣服，履物を着用し，1\%塩化ベンザ ルコニウム液（タケダ楽工 K.K 製）で手指を消毒し てから作業に従事した。飼育者は当飼育室專任で他の 飼育室と交流することはなかった。
交配，分婏用にはエコンケージ（日本クレア K.K 製）を，60日令までの育成ラットには $40 \times 50 \times 20 \mathrm{~cm}^{3}$ の金属ケージと金網ケージ（日本クレアK.K製）を使 用した。ケージも $1 \%$ 塩化ベンザルコニウム液で消毒 し, 床敷は $121^{\circ} \mathrm{C}, 30$ 分蒸気滅菌したものを用いた。 飼料は自家製の固型飼料を用い，水とともに自由摂取 させた。

$\mathrm{HI}$ 抗体：ラット血清は個体別に採取し 抗体の検索 をおこなった。血清には RDE (Receptor Destro-

Table 1 Occurence of epidemic respiratory disease in a rat colony from April 1961 to January 1970

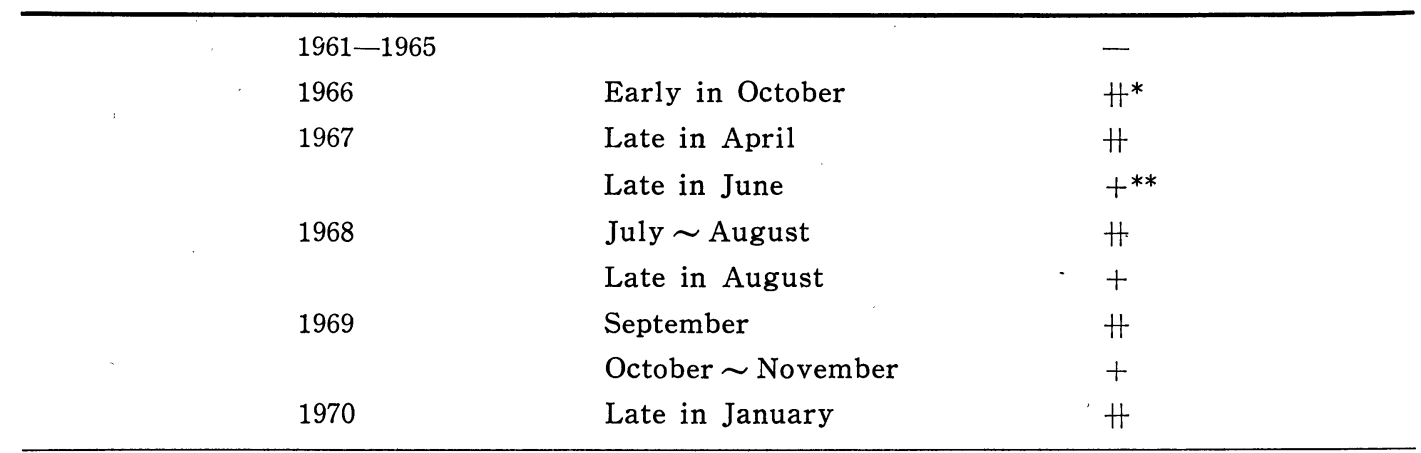

*Epidemy in which over $70 \%$ of animals were affected.

**Epidemy in which less than $50 \%$ of animals were affected.

Table 2 Body weight of suckling during epidemies and non epidemic periods from 1966 to 1970

\begin{tabular}{|c|c|c|c|c|c|c|c|c|c|c|c|c|}
\hline \multirow[b]{2}{*}{ Time } & \multirow[b]{2}{*}{ Sex } & \multirow[b]{2}{*}{$\begin{array}{c}\text { Age in } \\
\text { days }\end{array}$} & \multicolumn{5}{|c|}{ Non epidemic period } & \multicolumn{5}{|c|}{ Epidemic period } \\
\hline & & & $\begin{array}{c}\text { No. of } \\
\text { rats }\end{array}$ & Mean & \pm & S.D. & C.V. $(\%)$ & $\begin{array}{c}\text { No. of } \\
\text { rats }\end{array}$ & Mean & \pm & S.D. & C.V. $(\%)$ \\
\hline \multirow[t]{4}{*}{1966} & 우 & 10 & 18 & 21.9 & \pm & 2.5 & 11.6 & 19 & 16.7 & \pm & 3.9 & 24.5 \\
\hline & & 20 & 26 & 50.9 & \pm & 5.8 & 11.4 & 7 & 28.5 & \pm & 9.9 & 34.6 \\
\hline & $\hat{\delta}$ & 10 & 19 & 21.5 & \pm & 2.5 & 11.8 & 19 & 17.0 & \pm & 5.1 & 29.9 \\
\hline & & 20 & 24 & 48.0 & \pm & 7.8 & 16.2 & 6 & 33.9 & \pm & 8.9 & 26.2 \\
\hline \multirow[t]{4}{*}{1967} & 우 & 10 & 25 & 15.0 & \pm & 1.7 & 11.1 & 4 & 11.5 & \pm & 0.8 & 6.5 \\
\hline & & 20 & 23 & 35.4 & \pm & 4.9 & 13.7 & $*$ & & & & \\
\hline & $\hat{o}$ & 10 & 25 & 15.5 & \pm & 2.2 & 13.9 & 7 & 13.9 & \pm & 3.9 & 28.1 \\
\hline & & 20 & 20 & 37.5 & \pm & 4.3 & 11.4 & 3 & 34.2 & \pm & 3.6 & 10.6 \\
\hline \multirow[t]{2}{*}{1968} & 우 & 20 & 21 & 40.6 & \pm & 4.7 & 11.6 & 22 & 41.6 & \pm & 4.6 & 11.2 \\
\hline & $\hat{\delta}$ & 20 & 19 & 41.7 & \pm & 5.4 & 12.9 & 24 & 43.9 & \pm & 4.3 & 9.8 \\
\hline \multirow[t]{4}{*}{1969} & 우 & 10 & 16 & 20.9 & \pm & 3.4 & 16.4 & 8 & 19.6 & \pm & 5.1 & 26.1 \\
\hline & & 20 & 16 & 46.1 & \pm & 5.7 & 12.3 & 6 & 41.0 & \pm & 8.2 & 19.9 \\
\hline & $\widehat{o}$ & 10 & 21 & 22.9 & \pm & 2.8 & 12.3 & 8 & 20.4 & \pm & 5.5 & 27.2 \\
\hline & & 20 & 20 & 48.7 & \pm & 4.3 & 8.8 & 7 & 38.5 & \pm & 12.1 & 31.4 \\
\hline \multirow{4}{*}{1970} & 우 & 10 & 35 & 18.7 & \pm & 2.0 & 10.8 & 22 & 16.4 & \pm & 4.6 & 28.2 \\
\hline & & 20 & 34 & 39.9 & \pm & 3.7 & 9.2 & 15 & 37.7 & \pm & 5.9 & 16.0 \\
\hline & $\hat{0}$ & 10 & 33 & 20.3 & \pm & 14.4 & 14.4 & 10 & 16.0 & \pm & 5.6 & 34.5 \\
\hline & & 20 & 34 & 42.5 & \pm & 3.7 & 9.2 & 9 & 34.7 & \pm & 8.8 & 25.2 \\
\hline
\end{tabular}

Epidemic period in each year was designated as $\#$ in Table 1.

*Sucklings died before 20 day old. 
ying Enzyme, タケダ薬工 K.K 製) 溶液（生理食 塩水 $10 \mathrm{ml}$ 飞溶解）を 2 倍量加えて処理し, 血球凝集 抑制因子を除去した。さらに，20\%鶏血球浮遊液を血 清之等量加えて, 非特異的凝集素を吸收除去した。抗 原には発育鴊卵で継代したセンダイウイルス Z株をエ 一テルで不活化したものを用いた。

ウイルス検索 : ラットの肺を滅菌ーPBS で $10 \%$ 乳 剤として, $1,000 \mathrm{rpm}, 5$ 分遠心, 上清 $0.2 \mathrm{ml}$ ずつを 3 בの 8 日令発育鷄卵の羊膜腔内に接種し, $37^{\circ} \mathrm{C}, 3$ 日間眇卵後に, 1 コでも漿尿液が彩血球凝集性を示し たものをウイルス陽性と判定した。3 コとも陰性のも のについては, 羊膜拉よび漿尿膜の乳剤をプールし て, さらに 3 コの 8 日卵の羊膜腔内に接種し, 全例の 漿尿液が血球凝集性を示さない場合にはじめてウイル ス陰性とした。

Mycoplasma検索 : 滅菌-PBS 約 $0.5 \mathrm{ml}$ 鼻腔内, 約 $0.5 \mathrm{ml}$ を中耳腔に注入して得た洗條液および前項 に述ベたラットの肺乳剂を 1 白金耳量 $20 \%$ 馬血清加寒 天培地 (Pc. 1, 000I.U./ml 含む) に塗沫した。 $37^{\circ}$ C, 10日間培養し, 特異的な目玉焼状形態を呈するコ ロニーの発育をみたものを Mycoplasma として分離 し, 普通寒天培地で発育しないこと, 継代によってコ ロニー性状に変化のないことを確かめた。
成

\section{1. 発生状況}

Table 1 にしめすように, 9 年間の観察で呼吸器 病の発生が間けつ的にくりかえしみとめられた。発生 時にはラットはスナッフル症状を呈し, 鼻汁が鼻孔周 囲に付着し黒く污ごれているものが多く, 胸部聴診で は squeezing, bubling が観察された。離乳前の幼 若ラットの多くはケージ内で個々に離散し, “プチ ュ,プチュ”といら音を発した。 $3 \sim 4$ 週令ラットで は立毛, 摂䬣量の減少, 運動不活発がみとめられ, 一 部は発育不良が目立った。初回発生は1966年10月にお こり約 3 週間持続した。しかしこの流行が終ってか らは1967年 3 月までは発生がなかった。以後1967年 4 月から1970年 3 月までの 3 年間に 7 回の発生がみとめ られたが，その内 4 回は約 300 匹以上の発病例をみた 大規模の流行であり, 3 回は約 200 匹以下の比較的小 規模の流行であった。前者は $2-4$ 週, 後者は $1-2$ 週の経過で終息した。流行と次の流行との間隔は最短 約 2 週, 最長約 1 年であった。流行は夏一秋に多く発 生した。

呼吸器病の伝播速度は急速で, いずれの流行でも群 中少数の発病ラットが発見されてから数日で泳さ最 大の規模に達した。1967年 6 月, 1968年 8 月下旬, 19 69年10月の発生は比較的小規模で, 約 50-100 匹が発

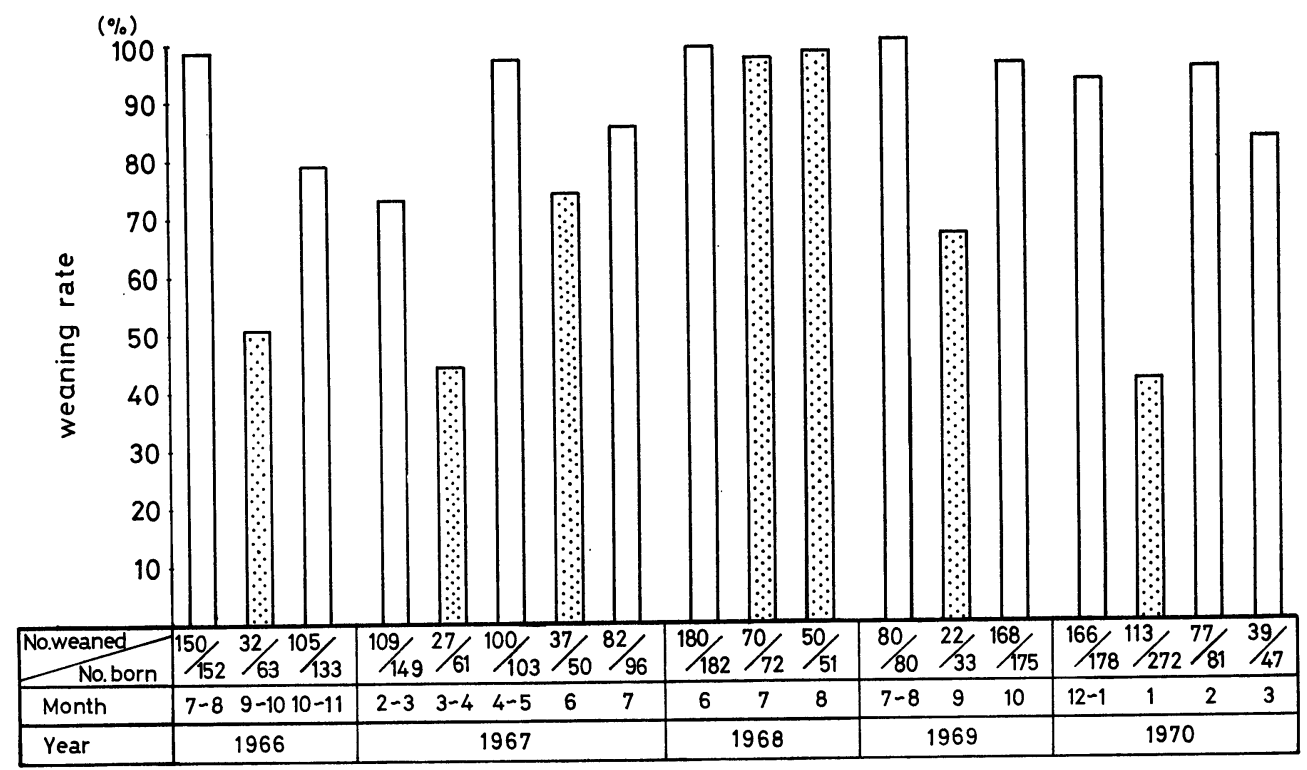

Fig. 1. Weanling rate during epidemies and non epidemic periods.

$\because \because$ : during epidemy.

: during non-epidemic period. 


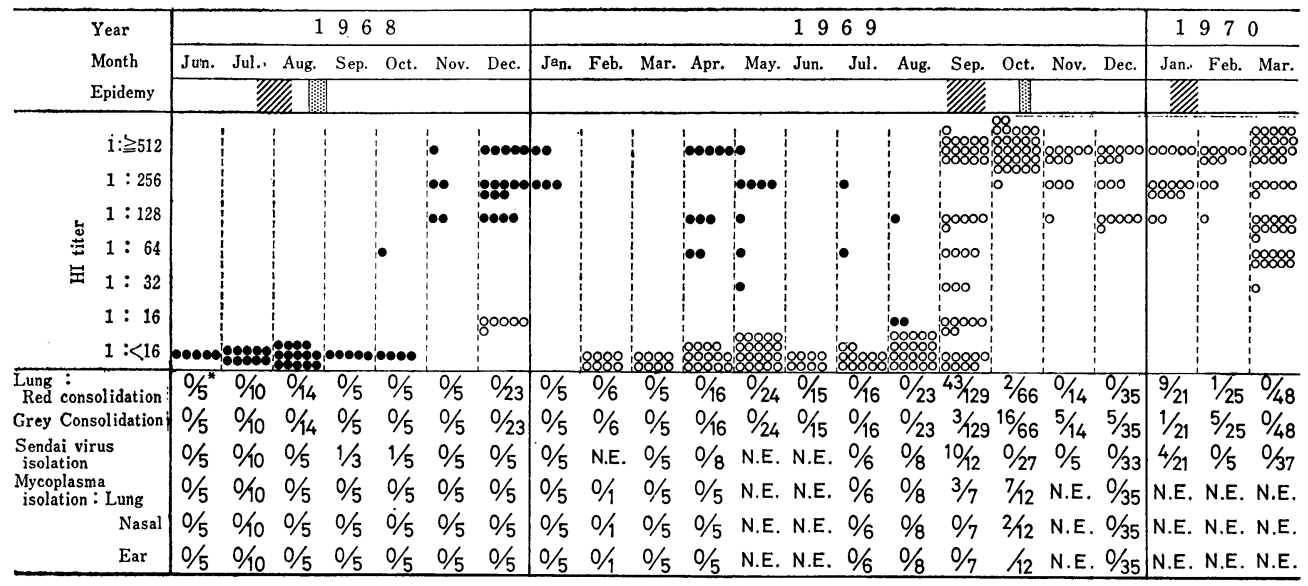

Fig 2 Pathological, serological \& epizootiological observations on rats from June 1968tcto March 1970.

"IIIIII/!: Epidemy was designated as $\#$ in table 1

$17.8 \%$ : Epidemy was designated as + in table.

$\square$ : Non epidemy.

- : Serum from rats born before October 1968.

- : Serum from rats born after November 1968.
* : No. positive/No. tested.

N.E. : Not examined
症したのみで，症状の持続期間も10日以内の短かいも のであったが，これらはいずれも約 1 ケ月前の大規模 な流行に続発したものであった。各流行期に括ける臨 床所見には軽・重の程度差は若干みとめられたが，本 質的には違いはなかった。また，1968年 7 月以後, 前 述したように，Wistar 系ラットが同居したが，流 行時には両者共に罹患し, 系統による感受性の差異は みとめられなかった。

\section{2. ラットの成長, 離乳成績}

1966一-1970年の非流行時と流行時に無作為に選んだ 10日令，20日令ラットの平均体重の比較を Table 2 に示した。流行時では, いずれも非流行時にくらべ10 日令, 20日令体重とも著明な体重差がみとめられた。 非流行時と流行時の個々の体重のバラツキを比較する ため, 変動係数を求めた。流行時の変動你数は著しく 大きく，20-30\%であった。例觉ば，1970年 1 月の流 行時では, 雌, 雄ともに, 10日令で10 g 前後, 20日令 で30 g 以下の極度に発育の悪い動物が多数みとめられ た。これらのほとんぞはケージ内で離散したまま整死 していた。また，20日令で発育不良の著明であったラ ットの体重は成熟後も標準に達することはなかった。 1968年の流行時だけは, 幼若動物の体重は全く影響を
受けなかった。

つぎに，1966-1970年までの非流行時と流行時との 離乳率〔離乳仔数：産仔数（3日令で 8 匹に間引き制 限）の比較を Fig. 1. 飞示す。流行時には非流行時 にくらべ30-40\%の低下がみとめられた。とくに, 19 66年10月, 1967年 4 月, 1970年 1 月は著明であった。 1968年の流行時は離乳率の低下はみとめられなかっ た。

\section{3. 肺の病変}

1968一-1970年に笔死または殺処分した動物はすべて 剖検したが，それらについて肺の病変の出現率を Fig. 2 に示した。1969年 9 月, および1970年 1 月の 流行時には，30-40\%の率で赤色肝变化がみとめられ た。しかし, これら流行の終息後には, 赤色肝変病巣 はほとんどみられず，代って線状の灰白色部，おそら くは線維化巣が多数例みられた。1969年 9 月の流行時 では, 親ラットにも多数赤色肝変化をみとめたが, 1970年 1 月の流行時では, 赤色肝変化をみとめた 9 例 はいずれも30日令未満の幼若ラットであった。1968年 6 月一 1969 年 8 月間には, 肺の病変は 1 例もみとめら れなかった。とくに, 1968年では, 夏の流行時にも肺 の病変はみられなかった。肉眼的に膿瘍形成をみとめ 
たものはなかった。

4. センダイウイルス分離と $\mathrm{HI}$ 抗体の検索 1968年一1970年 3 月までのウイルス検索成績および HI 抗体の月別分布を Fig. 2 に示す。1968年では, ウイルスは $7-8$ 月の流行消退後に,すなわち， 9 月 および10月にそれぞれ 1例ずつ親ラットから分離され た。1969年には，9月の流行発生直後に80\%の高率で 60日令前後のラットから分離された。しかし, その後 12月までの 3 ケ月間はすべて陰性であった。1970年 1 月の流行時では, ウイルスは約10日令の乳のみラット からのみ分離された。同時に検索した親ラットはすべ て陰性であった。

HI 抗体の検索成績を月別にみると，1968年 9 月ま ではすべて陰性であったが，1968年 9-10月の流行を 経過したラットは11月以降の検索ですべて陽性であっ た。その抗体価は1969年 4 月頃まで高く（1：64-1 : 512)，その後 8 月頃までに徐々に低下した。これに 反して, 最初の流行が終りウイルス分離も陰性となっ た1968年11月以降に生まれたラットでは，母親からの 移行抗体と考兄られる翌月の陽性例を除き, 次の流 行, つまり1969年 9 月以前には, HI 抗体陽性例は 1 例もなかった。しかし，1969年 9 月の大規模流行後は すべてが HI 抗体陽性となった。このように, 1969年 1ー8 月までの期間は, 同じコロニ一内で流行を経過 したラットと，しないラットが抗体の陽性・陰性によ って明確に区別された。

ウイルス分離と肺の肉眼所見および HI 抗体価の関 係をみると，1968年 9-10月にウイルスが分離された 2 例の肺には病変はみとめられず, $\mathrm{HI}$ 抗体も陰性で あった。1969年 9 月のウイルス陽性の10例, 1970年 1 月の陽性 4 例では, いずれも肺に著明な赤色肝変化を みとめたが，それらの HI 価は，1969年 9 月に検索し

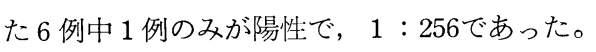

\section{Mycoplasma の分離}

1968年 6 月ー1969年12月までの Mycoplasma の分 離率と分離部位を Fig. 2 に示した。1969年 9 月の流 行時には約 $40 \%, 10$ 月では約 $60 \%$ の率で菌が分離され た。陽性例では肺からの分離例がほとんどで, 鼻腔, 中耳腔からの分離は29例中各々 2 例および 1 例にすぎ なかった。1968年の流行時では, 菌は 1 例も分離され なかった。

\section{考察}

9 年間に亘る観察で, 初期の 5 年間は臨床所見・剖 検所見で異常はみとめられなかった。しかし，1966年 からほ注同一型の呼吸器病の流行が間けつ的に数回発 生し, この間, 症状の発現・伝播に一致して血球凝集
性ウイルスが分離された。また，流行を契機としてラ ットコロニ一内のセンダイウイルス $\mathrm{HI}$ 抗体が多数例 陽性となった。丸らは1968年の流行時に分離した血球 凝集性ウイルスとセンダイウイルス伏見株との比較を おこない, 熱抵抗性 $\left(50^{\circ} \mathrm{C}, 5\right.$ 分), 中和試験, $\mathrm{HI}$ 試 験, およびセンダイウイルス陰性の 30 日令 SD-JCL ラット，ICR-JCL マウスを用いての経鼻感染実験か ら, この血球凝集性ウイルスはセンダイウイルスであ ると同定した（丸ら[3]）。また, 肺の著しい充血, 赤 色肝変化は流行初期に多数例にみとめられたが, 流行 の消退とともに陳旧な線維化病巣に変化したこと， ウイルス分離が陽性であったのは HI 抗体が出現する 前の短かい期間であったこと等の病変の移り変わり, 呼吸器病の一過性の経過は, Tyrrell ら〔4]のラッ トに打けるセンダイウイルス感染実験での急性肺炎, および笹原ら〔5]のセンダイウイルス感染豚の一過 性呼吸器症状, 林, 笹原ら $[6,7]$ がマウスに打ける センダイウイルス感染実験でみた肺の変化と一致して いる。以上のことから, 一連の呼吸器病はセンダイウ イルスに起因したと考兄れる。

ラットに拈けるセンダイウイルス感染実験で, Coid ら[8]は子宮内胎仔の吸収を報告しているが, 今回の 流行はいずれも短期間で, しかも, ラット集団が小さ いため分婏率への影響は解明出来なかった。しか し, 流行時には哺乳幼若ラットの死亡および発育不良 が多数観察され, 加藤 [9]がマウスコロニーで観察し たセンダイウイルス流行例で, 離乳率の低下, 仔の咬 殺等を報告しているのと同じであった。

Mycoplasma が分離された1969年 $9-10$ 月の流行 では, 離乳率の低下, 肺の肝变化, 幼若動物の発育不 良等をみとめたが，Mycoplasma の陰性であった 1968年夏の流行では, 離乳率にも, 幼若動物の体重に も, 異常はなかった。尾形ら〔10〕はラットの呼吸器 からの Mycoplasma の検出率と, 肉眼的病変および 呼吸器症状には密接な関係があるとしている。これら のことから，Mycoplasma が二次的に関与した場合 に, とくに幼若動物の病勢をより重症化することが考 えられる。

マウス集団にお゙ケるセンダイウイルスの流行はその ほとんどが enzootic なもので, epizootic な流行例 は Parker ら〔11〕がウイルス陽性の19のマウス集団 中わずか 1 例にみとめた他は, 福見ら〔12]の報告が あるのみで, ラット集団でのくわしい報告は見当らな い。今回我々が観察したセンダイウイルスの流行は Parker らのいう epizootic な流行に相当するもの であろう。Epizootic な流行が 8-10ケ月の間隔で 繰り返し発生した要因として, 感受性動物の集団内で 
の変動が考えられる。すなわち，繁殖育成場では常に 親集団は新しい動物に交替して招り，流行後10ケ月の 内には，流行を経過した親ラットはそのほとんどが淘 汰され，流行後に生まれた抗体陰性ラットが親集団を 形成するためである。污染源としては，一度感染を受 けた親ラットがウイルスの carrierになって扣り，流 行後 8 ケ月頃から抗体価の低下とともに顕性化し, infector となったのか，前述したように，近接して 位置するマウス育成場からの外部污染によったのかは 明らかでない。今後さらに追求する必要があろう。

\section{要 約}

1961年からの 9 年間に亘る観察で総数約 500 匹のラ ット繁殖育成コロニーに, 呼吸器症状を主徴とする疾 病の流行が 8一-10ケ月間隔でくりかえし発生し，その 多くは夏一秋にみとめられた。大規模の流行の場合， 蕒延は極めて速やかで，ほぼ 1 週間で全コロニーに波 及し， $2-3$ 週後には消退した。このような大規模の 流行終息から 2-6 週間おいて，小規模の流行がみら れる場合があった。流行時には, 幼若ラットの発育不 良, 離乳率の低下がみとめられた。発病ラットでは肺 の赤色肝変化が特徴的であり，そのような材料からは 血球凝集性ウイルスが分離され，センダイウイルス $\mathrm{HI}$ 抗体が症状, 肺病変の発現と一致して顕著に上昇 し，流行が終息してから 1 年後にも検出された。流行 の終息後に生まれたラットには, 生後1ケ月令では移 行抗体が検出されたが，その後新たな流行に遭遇する まですべて抗体陰性であった。1968年以後おこなった 検索では肺からの Mycoplasma の分離が陽性であっ たのは 1 回の流行のみであった。

終りに臨み愁篤なる教示と校閲を賜わった東大医科 研藤原公策教授，並びに本調査を命ぜられ，かつ指導 助言を賜わった峰下銕雄博士に厚く打礼申し上げる。 また，有益な助言を賜わった名古屋大学農学部藤尾芳 久博士, シオノギ研究所丸守正氏につつしんで感謝の 意を表する。

本論文の要旨は日本実験動物第 5 回研究発表会にお いて発表された。

\section{文献}

[1] Parker J.C., Tennant R.W., Ward T.G. (1 964). Enzootic Sendai virus infections in mouse breeder colonies within the $\mathrm{U}$. nited States. Science, 146, 936-938.

〔2〕朱宮正剛, 中村正義（1968）。大量生産に甡け
る疾病管理。日本実験動物研究会第 3 回発表 会, 於奈良。

［3〕丸守正，佐藤孝三郎（1971）．ラットコロニより分離した HVJ の性状について。日本実験 動物研究会第 6 回発表会, 於東京。

[4] Tyrrell, D.A.J., Path, M.C., and Coid, C. R. (1970). Sendai virus infection of rats as a convienient model of acute respiratory infection. The Veterinary Record, $86,164-165$.

[5] Sasahara Jiro, Hayashi Shigemi, Kumagai Tetsuo, Hirasawa Sumi, Munakata Kozo, Okaniwa Azusa, Kato Kazuyoshi (1954). A swine disease newly discovered in Japan. Its characteristic traits of pneumonia (III). Virus, 4, 297-301.

[6] Hayashi Shigeyoshi (1961). Studies on the infection of Myxovirus parainfluenza 1 (HVJ) in the experimental small animals. Virus, 11, 108-119.

[7] Sasahara Jiro, Kumagai Tetsuo, and Kato Kazuyoshi (1954). A swine disease newly discovered in Japan. Its characteristic traits of pneumonia (IV). Virus, 4, 302 -308 .

[8] Coid, C.R., Wardman, G. (1971). The effect of para-influenza type 1 (Sendai) virus infection on early pregnancy in the rat. J. Reprod. Fert., 24, 39-43.

〔9]加藤和好 (1959). マウスに於けるMyxovirus para-influenza 1 （HVJ） の流行とその長期 観察について。実験動物, 8, 94-98.

〔10〕尾形学, 大島康夫, 長田恭明 (1968). ラット の Mycoplasma V関する研究. I. 呼吸器の Mycoplasma 検索について。日本獣医学雑誌, 30, 265-274.

[11] Parker J.C., Reynolds R.K. (1968). Natural history of Sendai virus infection in mice. American Journal of Epidemiology, 88, 112-125.

[12] Fukumi, H., Mizutani, H., Takeuchi, Y., Tajima, Y., Imaizumi, K., Tanaka, T. and Kaneko, J. (1962). Studies on Sendai virus infection in laboratory mice. Jap. J. Med. Sci. Biol., 15, 153-163. 